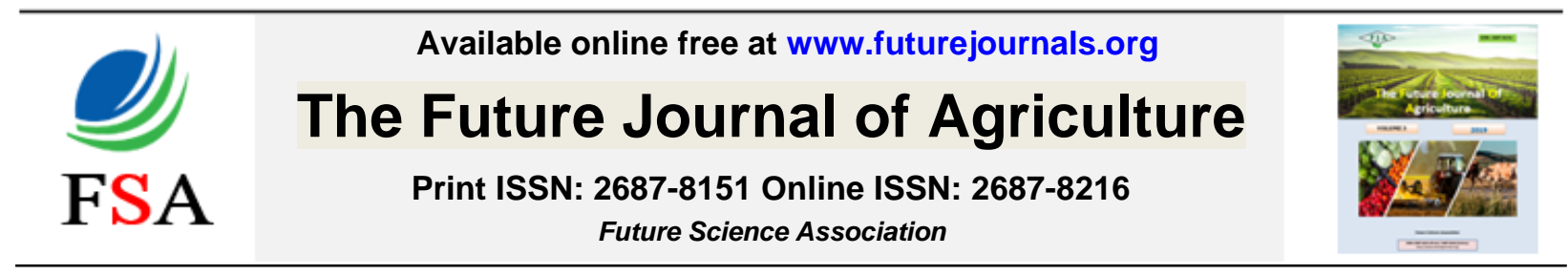

Future J. Agric., 3 (2020) 5-9

OPEN ACCES

DOI: 10.37229/fsa.fja.2020.07.02

\title{
CALLUS INDUCTION AND DIFFERENTIATION (Review Article)
}

\author{
Aysar M. S. Almemary \\ Horticulture and landscape department, College of Agriculture and Forestry, Mosul University, Iraq. \\ *Corresponding author: aysaralsalim@yahoo.com Received: 26 May 2020 ; Accepted: 2 July 2020
}

\begin{abstract}
The science of plant tissue culture is the science of developing plant cells, tissues, or organs isolated from the mother plant or cell protoplast on culture media (George et al., 2008). The technology of plant tissue is one of the biotechnologies that led and still plays an important role in the service of man, especially in the field of propagation of many types of plants because of the advantages of this method, perhaps the most important of which is obtaining huge numbers of plants without pathogens and similar to the mother plant at a time relatively short and at any time of the year, in addition to using this technology in research and application fields, including breeding Plant improvement, production of medicinal drugs, drugs, and rapid breeding multiplication are among the applications of great importance that are followed by different methods of differentiation and formal formation such as the formation of transverse buds, stimulation of the growth of axillary buds and the development of asexual embryos (somatic embryos) as well as a study of the basic aspects of plant growth and development and secondary metabolism (Al-Kinani, 2002; Ford, 2000; Kasumi et al., 2004 and Gupta et al., 2006).
\end{abstract}

Key words: Callus, induction, differentiation, tissue culture.

\section{INTRODUCTION}

Callus tissue is a grouping of parenchyma cells irregularly shaped formed on the wound or cutting areas of the plant. This callus can be developed by growing different plant parts, whether it is leafy, leafy, stem, knot or part of a tuber on agricultural media equipped with one of auxins types., the cells of the plant explant, during the development and growth of callus, undergo certain changes, namely, the change in size, number, and composition, in addition to a significant increase in some important structural processes such as protein building and nucleic acids. It is preferable to sustain callus farms by replanting the subculture every three to four weeks (Hartman et al., 2002). This tissue is usually used to multiply plants by growing tissues by differentiating them into a process called organogenesis by cultivating this unspecialized tissue on media containing on auxins and cytokinin, by balancing the internal hormones with exogenous organizations, the formation of branches and roots, or both, is controlled. The growth of callus depends to a large extent on the components of the nutritional medium in terms of the concentration of nutrients and their proportions, as well as the conditions used in its cultivation, and the growth of callus is determined in various ways, namely the measurement of soft weight, dry weight and the content of callus cells from the basic cellular components such as protein and carbohydrates or sometimes calculating the number of cells that make up the callus tissue. The measurement of the soft weight of the callus is a clear and fast indicator of the rate of callus growth after noting that the callus mass has increased over the culture medium. (Muhammad and Omar, 1990 and Al-Hadidi, 2002). Mosquera et al. (2006) obtained callus from planting pollen for carnation plant on MS medium containing 1.0 $\mathrm{mg} / \mathrm{L}$ 2,4-D with $1.0 \mathrm{mg} / \mathrm{L}$ BA while keeping 
crops in total darkness. for five weeks. Researchers Kumar and Kanwar (2007) reported that cultivating portions of the leaf of the G. Jamesonii plant on an MS medium equipped with 1.5 or $2 \mathrm{mg} / \mathrm{L} \mathrm{2,4-D}$ gave the highest response rate for callus induction 95 and $7.93 \%$ respectively and was of a fragile texture and after transferring the callus to the MS medium equipped with $1,1.5,2,3$ or 5 $\mathrm{mg} / \mathrm{L}$ BA or Kin the branches consisted of $75 \%$ and the number of branches 9 branches / vegetable part of cultivation on medium supplied with $3 \mathrm{mg} / \mathrm{L}$ BA. Karami et al. (2008) stated that he obtained callus from cultivation of cotyledons, petals and sepals of carnation plant on MS medium containing $2.0 \mathrm{mg} / \mathrm{L} \mathrm{2,4-}$ D with $0.2 \mathrm{mg} / \mathrm{L} \mathrm{BA}$ as the petals formed 80 $85 \%$ somatic embryos when they were transported to a hormone-free MS medium containing a small amount of $2,4-\mathrm{D}(0.2 \mathrm{mg} / \mathrm{L})$ .In a study by Altaf $\boldsymbol{e t}$ al. (2009) they found that the cultivation of gerbera seedlings on MS medium equipped with $\mathrm{BA}$ and 2,4-D at a concentration of $3 \mathrm{mg} / \mathrm{L}$ each gave the highest Callus initiation rate $41 \%$ after 6 weeks of transplantation and when transferring the resulting callus to the MS medium equipped with $4 \mathrm{mg} / \mathrm{L} \mathrm{BA}$ with $1 \mathrm{mg} / \mathrm{L}$ IBA gave the highest rate of number of branches 29 / part plant, after two months of cultivation. Almemary (2009) stated that the cultivation parts of the leaves of the white variety Jeanne Dionis Blano on the medium of MS equipped with $2.0 \mathrm{mg} / \mathrm{L} \mathrm{2,4-D} \mathrm{gave} \mathrm{the} \mathrm{highest} \mathrm{response}$ rate of callus development $100 \%$ after 4 weeks of cultivation and then the callus differentiation when transported to the medium of MS added with concentrations of NAA and that the highest percentage of formation of branches and roots $60 \%$ was obtained from the addition of 1 $\mathrm{mg} / \mathrm{L}$ NAA with an average number of branches of 10.30 branches with a length of $1.70 \mathrm{~cm}$ and an average number of roots of 2.80 root. Fatima et al. (2009) confirmed that they had the highest callus generation rate of $88,06 \%$ and the highest average wet and dry weight of $2.58 \mathrm{~g}, 0.29 \mathrm{~g}$, respectively, from the cultivation of Digitalis lanata leaves on an MS medium of $6 \mathrm{mg} / \mathrm{L}$ NAA, while leaves grown on MS medium with $6 \mathrm{mg} / \mathrm{L}$ 2,4-D gave the highest callus content $56.33 \%$ and wet and dry weight rates of 2.09 and $0.27 \mathrm{~g}$ respectively after 12 weeks of cultivation. Al-Shahwani (2010) stated that the use of different concentrations of SA encouraged the growth of black seed nigella sativa $L$., and that the concentration of 6.90 $\mathrm{mg} / \mathrm{L}$ SA gave the highest soft weight $11.139 \mathrm{~g}$ at the age of 90 days compared to the weight of the growing callus in a medium free from SA, a differentiation of callus was obtained at a concentration of $1.38 \mathrm{mg} / \mathrm{L} \mathrm{SA}$ after 60 days and the formation of vegetative branches with 10 branches / plant part and $4 \mathrm{~mm}$ in length and with the number of roots 4 roots with a length of $3 \mathrm{~mm}$. The same researchers also mentioned that cultivation same plant on MS media with $10.35 \mathrm{mg} / \mathrm{L} \mathrm{SA}$ formed branches at a rate of 8 branch / vegetated part with a length of $33 \mathrm{~mm}$ after 45 days of cultivation. Paduchuri et al. (2010) mentioned the possibility of cultivating portions of the leaf of the G. Jamesonii plant on MS medium equipped with different concentrations of 2,4-D, NAA, Kin, BA for the purpose of developing callus and the highest incidence of callus development was $9.97 \%$ of cultivation on medium supported with $2 \mathrm{mg} / \mathrm{L}$ BA with $5.2 \mathrm{mg} / \mathrm{L}$ 2,4-D and had a solid texture and a whitish cream color 20 days after planting.

In a study by Shabbir et al. (2012) on the Gerbera G. Jamesonii plant, Sunglow cultivar showed that cultivation of portions of the leaf on MS medium equipped with IBA, NAA and 2,4-D at concentrations $1,1.5,, 2,2.5$ or $3 \mathrm{mg} / \mathrm{L}$ interfered with BA or Kin at concentrations 1 , $2,, 3,4 \mathrm{or} 5 \mathrm{mg} / \mathrm{L}$ resulted in the introduction of callus on the outer ends of the parts of the cultivated leaf and on all studied parameters except for those equipped with Kin one had a $100 \%$ higher response from cultivation on the supported medium of $1.5 \mathrm{mg} / \mathrm{L}$ 2,4-D and was of a fragile, loose and loose texture and a bleached cream color, and by replanting on media supported with the same concentrations of BA and Kin resulted in obtaining the highest percentage of branch formation was $67.76 \%$ from the supported medium by $3 \mathrm{mg} / \mathrm{L}$ BA, which gave the highest average number of branches (4) branch / plant part of $9 \mathrm{~cm}$ length, while the same concentration of Kin gave a response rate of $67,16 \%$ and number of branches 97 and with a length of $5.16 \mathrm{~cm}$. Vardhan et al. (2012) stated that the cultivation leaves of Pancy plant on the medium of MS equipped with $2.0 \mathrm{mg} / \mathrm{L} \mathrm{2,4-D}$ gave the highest callus after 6-8 weeks. Verma et al. (2012) stated that cultivate parts of the leaves of the Pancy plant on MS medium 
equipped with $4.0 \mathrm{mg} / \mathrm{L}$ 2,4-D the highest percentage of callus was given $76 \%$ as for cultivation on MS medium equipped with 4.0 $\mathrm{mg} / \mathrm{L}$ BA with $0.5 \mathrm{mg} / \mathrm{L} \mathrm{2,4-D} \mathrm{the} \mathrm{percentage}$ of callus was $78 . \%$. Al-Saleh and Al-Katib (2011) showed that planting the stem of the Pancy plant of Al-Bazoun plant on the medium of MS supplied with $0.5 \mathrm{mg} / \mathrm{L}$ BA with 1.0 $\mathrm{mg} / \mathrm{L}$ NAA resulted in the development of callus by $90 \%$ after 3 weeks of cultivation and then differentiated callus to vegetative branches after planting on the medium of MS supplied with $0.5 \mathrm{mg} / \mathrm{L}$ NAA with $1 \mathrm{mg} / \mathrm{L}$ BA was the highest average number of branches formed 9 branch / plant part length of $4.7 \mathrm{~cm}$.

\section{Somatic embryos}

The formation of somatic embryos is one of the methods of vegetative propagation in order to form a plant similar to the parent plant. The embryos form either directly on the plant part or by the formation of callus. This process is carried out through three stages: the induction phase, the division stage, and the differentiation stage. Formed cells have special features called (Embryonic cells) and develop into three phases, the spherical, cardiac, and torpedo (Muhammad and Omar, 1990). Raja et al. (2000) were able to obtain somatic embryos from the callus cultivation resulting from the cultivation of saffron pieces leaves Crocus sativus on MS medium equipped with 2.25

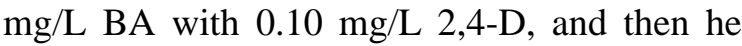
grows this embryo callus by planting it on medium. MS equipped with $1.75 \mathrm{mg} / \mathrm{L}$ IBA with $0.5 \mathrm{mg} / \mathrm{L} \mathrm{BA}$ with $0.20 \mathrm{mg} / \mathrm{L} \mathrm{GA}_{3}$ the branches began to develop 30 days after the formation of somatic embryos. Sage et al. (2000) obtained somatic embryos from cultivation of various parts of the Narcissus pseudonarcissus Harvest Golden and St. Keverne variety represented by parts of the leaf blade or leaf base or longitudinal slices of the bulb or flower stalk on the MS medium equipped with 2,4-D and BA in different concentrations, most embryos were obtained from syphilis transplantation on the medium provided with $1 \mathrm{mg} / \mathrm{L} \mathrm{2,4-D} \mathrm{or} 0.1 \mathrm{mg} / \mathrm{L} 2,4-\mathrm{D}$ or $1 \mathrm{mg} / \mathrm{L}$ BA after 4 weeks of implantation. Kasumi et al. (2004) managed to obtain somatic embryos by cultivating pieces of the root of the grandiflora cultivar on MS medium equipped with $5 \mathrm{mg} / \mathrm{L}$ NAA with $5 \mathrm{mg} / \mathrm{L} \mathrm{BA}$.
Kedra and Bach (2005) were able to obtain somatic embryos from the Lilium martagon L. callus resulting from the cultivation of different portions of seedlings (embryonic peduncles, seedlings bulbs, roots) and transverse bulbs on MS medium equipped with different concentrations of BA and Picloram. The largest number of embryos were obtained from culture at $1 \mathrm{mg} / \mathrm{L}$ Picloram with $1 \mathrm{mg} / \mathrm{L}$ BA. Darvishi et al. (2006) were able to obtain embryo callus from Crocus sativus apical transplantation on a medium LS processed 1 $\mathrm{mg} / \mathrm{L}$ 2,4-D with $2 \mathrm{mg} / \mathrm{L} \mathrm{BA}$, and when developing this embryo callus on the same medium obtained the embryos that developed Later on to branches and leaves, then plants and then creams. Anbari et al. (2007) reported that the largest number of narcissus bulbs Narcissus Papyraceus Shirazi cultivar was obtained directly from the cultivation of bulbs slices on MS medium equipped with $0.5 \mathrm{mg} / \mathrm{L} \mathrm{GA}_{3}$ with $1.6 \mathrm{mg} / \mathrm{L} \mathrm{BA}$ with $1.6 \mathrm{mg} / \mathrm{L} \mathrm{2,4}$-D and was able to double the number of physical embryos when planted on MS medium without growth regulators. Ptak and Bach (2007) had the highest incidence of somatic embryos from the cultivation of parts of the flower stem of the Tulipa gesneriana L. Apeldoorn variety with a MS medium equipped with $6 \mathrm{mg} / \mathrm{L}$ Picloram with $0.1 \mathrm{mg} / \mathrm{L} \mathrm{BA}$, embryos evolved to reach the torpedo phase when they were transported to $\mathrm{MS}$ medium equipped with $1 \mathrm{mg} / \mathrm{L} \mathrm{BA}$ with $0.1 \mathrm{mg} / \mathrm{L}$ NAA . Emek and Erdage (2007) cultivated pieces of gladiolus leaves Anatolicus cultivar produced from tissue culture on MS medium equipped with different concentrations of NAA and found that the best Callus were in the medium equipped with $5 \mathrm{mg} / \mathrm{L} \mathrm{NAA}$ and obtained somatic embryos from this callus when implanted on the MS medium equipped with $0.1 \mathrm{mg} / \mathrm{L} \quad$ BA after 8 weeks of implantation. Gao et al. (2009) were able to obtain somatic embryos directly from the cultivation of the vegetable parts of the young inflorescence and the flower-neck of Freesia X hybrida Baiely on MS medium equipped with 2 $\mathrm{mg} / \mathrm{L}$ IAA with $1 \mathrm{mg} / \mathrm{L} \quad \mathrm{BA}$ and the development rate was $84 \%$ of the young inflorescence and with a rate at of $100 \%$ of the neck of the florets, as well as somatic embryos formed on callus obtained from the cultivation of the same parts on the medium of MS equipped with $5 \mathrm{mg} / \mathrm{L} \mathrm{BA}$ with $1 \mathrm{mg} / \mathrm{L}$ 2,4-D and somatic embryos were created at a rate of 
$92.4 \%$ of the flowers of the young inflorescence callus and $100 \%$ of neck florets callus, after which the embryo callus was transferred and transplanted to MS medium equipped with 2 $\mathrm{mg} / \mathrm{L}$ IAA with $3 \mathrm{mg} / \mathrm{L} \mathrm{BA}$ and developed into whole plants. Lee et al. (2009) managed to obtain somatic embryos from the cultivation of immature flowers of the Cnidium officinale plant (Raisomaceous medicinal plant) and with 12.3 somatic embryos / plant fragments on MS medium equipped with $1 \mathrm{mg} / \mathrm{L} 2,4-\mathrm{D}$ with 0.1 $\mathrm{mg} / \mathrm{L}$ BA after 5 weeks from transplantation. Nagesh et al. (2010) were able to obtain the highest rate of somatic embryos 23/g from embryo callus cultivation for Curculigo orchioides (tuberous medicinal plant) on MS medium equipped with $1 \mathrm{mg} / \mathrm{L} \mathrm{BA}$, the embryos formed were transported to the MS medium with half the concentration of salts it is devoid of growth regulators and notes that 90\% of the somatic embryos have evolved into whole plants. Karalija et al. (2010) obtained 20 embryos / plant part 30 days after planting pieces of Lilium martagon L. leaf Cattaniae vis cultivar on medium MS equipped with 0.5 $\mathrm{mg} / \mathrm{L} \mathrm{2,4} \mathrm{D}$ with $4 \mathrm{mg} / \mathrm{L}$ BA. Talebi $\boldsymbol{e t}$ al. (2012) obtained a small-scale calls from the cultivation of the leaves of the Catharanthus roseus plant on MS medium of $5.0 \mathrm{mg} / \mathrm{L} \mathrm{NAA}$ with $1 \mathrm{mg} / \mathrm{L}$ BA. Molchan et al. (2012) planted the Vinca minor leaves on an MS medium with a $0.2 \mathrm{mg} / \mathrm{L}$ NAA and obtained the largest amount of callus and fresh weight $9.5 \mathrm{~g}$ after 7 weeks of cultivation. Almemary (2014) planted parts of Catharantus roseus leaves on MS medium with $0.75 \mathrm{mg} / \mathrm{L} 2,4-\mathrm{D}$ or from adding 1 $\mathrm{mg} / \mathrm{L}$ BA led to the formation of callus, which differentiated into branch-like growths by 11.6 12.0 , respectively, 50 days after planting.

\section{Conclusions}

Callus can be developed from planting any part of the plant on auxins at certain concentrations or interfering with cytokines or it is obtained from cultivation on a medium free of growth regulators, and this depends on the plant part planted and its content of the natural hormone, and therefore this calcification differentiates into buds and roots after being somatic embryos and the stages through which the cells pass through to the entire plant in a short time and under controlled conditions and in large number.

\section{REFERENCES}

AL-Hadidi. M.A.H (2002). Experiments in Tissue Culture. Thought House for Printing and Publishing. Amman Jordan.

Al-Kinani, F.R (2002). Tissue culture and plant cells. House for Printing and Publishing. University of Mosul, Iraq.

\begin{abstract}
Almemary, A.M.S. (2009). Response of tow cultivars of Dianthus caryophyllus to propagation in vitro. M.Sc. Thesis, College of Agriculture and Forestry, University of Mosul. Ministry of Higher Education and Scientific Research. The Republic of Iraq.
\end{abstract}

\begin{abstract}
Almemary, A. M.S. (2014). Callus induction and differentiation from some explants of Catharanthus roseus L. and differentiation of some alkaids. Ph.D. Thesis, College of Agriculture and Forestry, University of Mosul. Ministry of Higher Education and Scientific Research. The Republic of Iraq.
\end{abstract}

Al-Saleh, S. Hanaa and Al-Katib, M.A. (2011). Formation of callus plantations for the vinca plant and extraction of phenolic compounds from it. Second Scientific Conference for Life Sciences, College of Science, University of Mosul, Iraq.

AL-Shahwani, A.A.H (2010). Biochemical study on the role of salicylic acid as a growth regulator in plant tissue metabolism of Nigella sativ L. plant. Ph.D Thesis. Collage of Science, University of Mosul, Iraq.

Altaf, N.; Khan, A.R.; Ali, L. and Bhatti, I. A. (2009). Tissue culture of Gerbera. Pak. J. Bot., 41(1): 7-10.

Anbari, S.; Tohidfar, M.; Hosseini, R. and Haddad, R. (2007). Somatic embryogenesis induction in Narcissus papyraceus cv. Shirazi. Plant Tiss. Cult. \& Biot., 17(1): 37- 46.

Darvishi, E.; Zarghami, R.; Mishani, C. A.; Omidi, M. and Sarkhosh, A. (2006). In vitro production of pathogen - free plantlets via meristem culture in saffron (Crocus sativus). Biotechnology, 5(3): 292- 295.

Emek, Y. and Erdage, B. (2007). Somatic embryogenesis from leaf explants of Gladiolus anatilicus. Pak. J. Boil. Sci., 10 (8): 1190- 1194.

Fatima, Z.; Abdul Mujib; Fatima, S.; Arshi, A. and Umar, S. (2009). Callus induction biomass growth and plant regeneration in Digitalis lanata Ehrh.: Influence of plant growth regulators and carbohydrates. Turk. J. Bot., 33: 393-405. 
Ford, K. G. (2000). Biological and Biomedical Science: Plant Science. Botany -General. McGraw - Hill com. pp. 1-6.

Gao, X.; Yang, D.; Cao, D.; Ao, M.; Sui, X.; Wang, Q.; Kimatu, J. N. and Wang, L. (2009). In vitro micropropagation of Freesia hybrida and the assessment of genetic and epigenetic stability in regenerated plantlets. J. Plant Growth Regul.

George, E. F.; Hall. M. A. and De Klerk, G. (2008). "Plant Propagation by Tissue Culture" $3^{\text {rd }}$ Edition. Volume 1. The Background. Springer.

Gupta, S.; Dutta, A. and Ibarakl, Y. (2006). Plant Tissue Culture Engineering. Vol. 6. The Background. Springer, 469 pages.

Hartmann, H. T.; Kester, D. E.; Davies, F. T. and Geneve, R. L. (2002). Plant. Propagation Principles and Practices. $7^{\text {th }}$. ed. Perntice Hall. Inc. New Jersey. USA.

Karalija, E.; Trbojevic, S. and Paric, A. (2010). Somatic embryogenesis and In vitro plantlet regeneration of Lilium martagon L. var. Cattaniae Vis. Biologica Nyssana, 1(2): 57- 60.

Karami, O. (2008). Induction of embryogenic callus and plant regeneration in carnation (Dianthus caryophyllus L.) J. Biological Sci., 8 (4): 68 - 72 .

Kasumi, M.; Takatsu, Y.; Suzuki, K.; Gonai, T.; Nogi, M.; Yamada, T. and Manabe, T. (2004). Callus formation and plant regeneration from root explant of Gladiolus (Gladiolus X grandiflora). Hort. J. JPN. Soc., 4(1): 7.

Kedra, M. and Bach, A. (2005). Morphogenesis of Lilium martagon L. explants in callus culture. Acta Biologica Cracoviensia Series Botanica, 47(1): $65-73$.

Kumar, S. and Kanwar, J.K. (2007). Plant regeneration from cell suspensions in Gerbera Jamesonii Bolus. J. F. and O.P. R., (15):157-166.

Lee, C.Y.; Kim, Y. K.; Kim, Y. S; Su, S. Y.; Le, S. Y. and Park, S.U. (2009). Somatic embryogenesis and plant regeneration in Cnidium officinale Makino. J. Medicinal Plants, 3 (3): 096 -100 .

Molchan, O.; Romashko, S. and Yurin, V. (2012). Ltryptophan decarboxylase activity and tryptamine accumulation in callus cultures of Vinca minor L. Plant Cell, Tiss. and Org. Cult., 108: 535-539.

Mosquera, T.; Rodriguez, L. E.; Parr, A. and Rodriguez, M. (2006). In vitro adventive regeneration from carnation (Dianthus caryophyllus) anthers. Acta Horticultural, 482: $305-308$.

Muhammad, A.A.S and Omar, M.S (1990). The main Conceots in plant tissue and organ transplation. Printing and Publishing, Universty of Mosul, Iraq.

Nagesh, K.S.; Shanthamma, C. and Pullaiah, T. (2010). Somatic embryogenesis and plant regeneration from callus cultures of Curculigo orchioides Gaertn. Indian J. Biotechnol, 9: 408 413.

Paduchuri, P. Y.; Deogirkar, G. V.; Kamdi, S. R.; Kale, M. C.; and Rajurkar, M. D. (2010). In vitro callus induction and root regeneration studies in Gerbera jamesonli. Int. J. of A. bio. and R., 1(2) :87-90.

Ptak, A. and Bach, A. (2007). Somatic embryogenesis in Tulip (Tulipa gesneriana L.) flower stem cultures. In vitro Cellular and Developmental Biology - Plant, 43 (1): 35 - 39.

Raja, W.; Zaffer, G.; and Wani, S.A. (2000). In Vitro microcorm formation in Saffron (Crocus sativus L.). University of Agricultural Scien Technology of Kashmir Shalimar Srinagar - 119121.

Sage, D.O.; Lynn, J. and Hammatt, N. (2000). Somatic embryogenesis in Narcissus pseudonarcissus cvs. Golden Harvest and St. Keverne. Plant Science, 150: 209 - 216.

Shabbir, K.; Ahmad, T.; Hafiz, I.A.; Hussaim, A.; Abbas, N.A. and Ahmad, J. (2012). In vitro regeneration of Gerbera jamesonii cv. Sunglow. Afr. J. Bio., 11(42) 9975- 9974

Talebi, M; Eatesam, F. and Sayed-Tabatabaei, B. E. (2012). Indirect regeneration from in vitro leaf tissue of periwinkle (Catharanthus roseus $\mathrm{L}$.) in response to different treatments of plant growth regulators. J. Sci. and Technol. Greenhouse Culture, 2: 8.

Vardhan, S.; Yadav, A.K.; Suri, R.K. and Nag, B.B.S. (2012). Genetic relatedness and in vitro antimicrobial activities of alkaloids isolated from Indian varieties of (Catharanthus roseus L.). Current Botany, 3(4): 43-48.

Verma, A.K.; Singh, R.R. and Singh, S. (2012). Improved alkaloid content in callus culture of Catharanthus roseus. Botanica Serbica., 36(2):123-130. 